\title{
Kiborzi i »djeca po narudžbi« 2.0: prihvaćenost koncepcija poslijeljudskog života u hrvatskom društvu
}

\author{
Krunoslav NIKODEM \\ Odsjek za sociologiju Filozofskog fakulteta Sveučilišta u Zagrebu, Hrvatska \\ knikodem@ffzg.hr \\ Ivana BRSTILO \\ Odjel za sociologiju, Hrvatsko katoličko sveučilište, Hrvatska \\ ivana.brstilo@unicath.hr
}

\begin{abstract}
Razvoj suvremene biotehnologije i bioznanosti otvara mnoge mogućnosti, pitanja i prijepore, ne samo u smislu općih društvenih, kulturnih i ekonomskih promjena, nego i u smislu promjena u izgradnji ljudskog identiteta i kriterija određivanja samoga ljudskog bića. U teorijskom smislu rad se temelji na teorijskim stajalištima posthumanizma, transhumanizma i biokonzervativizma. U empirijskom smislu rad se temelji na rezultatima empirijskog istraživanja provedenog 2009. godine na reprezentativnom uzorku punoljetnog stanovništva Hrvatske (N = 1000). U radu se analiziraju dvije koncepcije poslijeljudskog života: »kiborg« i »dijete po narudžbi«. Opća hipoteza rada jest da će spomenute koncepcije poslijeljudskog života, s obzirom na pretpostavljenu tradicionalnost sociokulturnog konteksta hrvatskog društva, biti prihvaćene tek u manjoj mjeri. Osim toga, u radu se postavlja i više radnih hipoteza. Dobiveni rezultati potvrđuju opću hipotezu rada, dok dio radnih hipoteza nije potvrđen.
\end{abstract}

Ključne riječi: poslijeljudsko, posthumanizam, transhumanizam, biokonzervativizam, kiborg, »djeca po narudžbi«

\section{Uvod}

»Shvaćaš li ozbiljnost takve tvrdnje, Powell?« Ta rečenica, napisana prije sedamdeset i jednu godinu, odgovor je robota (QT-I-a) ljudskom biću (Gregoryju Powellu) na njegovu tvrdnju da su tog robota sastavila dva ljudska bića. Riječ je o dijalogu s početka kratke priče Isaaca Asimova koja je pod naslovom »Reason« objavljena 1941. godine. Robot Cutie (QT-I) postavlja pitanje o svom porijeklu te nakon naznačenog odgovora, uz obrazloženje o 
ljudskom stvaranju robota, i nakon daljnjeg obrazloženja o ljudima, planetu Zemlji i robotima kao radnicima, postavlja sljedeće pitanje: »Očekuješ li od mene da povjerujem u jednu tako složenu i nevjerojatnu hipotezu kakvu si upravo izrekao? Što ti misliš da sam ja? (Asimov, 1993: 62, 64).

Razvoj suvremenoga tehnoznanstvenog sustava, posebice kibernetike, računalne tehnologije i biotehnologije, otvara mnoge mogućnosti, pitanja i prijepore, ne samo u smislu općih društvenih, kulturnih i ekonomskih promjena, nego i u smislu promjena u izgradnji ljudskog identiteta i kriterija određivanja samoga ljudskog bića. Naime, smatramo posve jasnim da je dominantno područje napredovanja znanosti i tehnologije u 21. stoljeću upravo područje ljudskog tijela i svijesti. Stoga više nije dovoljno razmatrati dva pravca širenja tehnoznanstvenog sustava: prvi, prema prirodi, što označava kolonizaciju prirode, i drugi, prema društvu, gdje društvo sve više postaje tehnološki ovisnim, nego je nužno razmatrati i treći pravac širenja tehnoznanstvenog sustava gdje se ljudsko postavlja kao konačna granica (Nikodem, 2004a: 182; Nikodem, 2008). Biotehnološko »poboljšavanje« ljudskog života, u konačnici usmjereno k »novom stvaranju«, u općem smislu opravdava se opstankom ljudske vrste. »Mi smo svoju okolinu tako radikalno izmijenili da sada moramo izmijeniti i sami sebe da bismo mogli opstati u toj novoj okolini« (Wiener, 1964: 65).

Osnovni pojmovi i koncepcije ovog rada su »kiborg«, »dijete po narudžbi«, »poslijeljudsko« i »posthumanizam«. Pojam »kiborga« (kibernetički organizam) označava živi organizam unutar kojega je ugrađen stroj što donosi promjene i poboljšanje funkcija tog živog organizma. Kiborg je organizam koji je dijelom živo biće, a dijelom stroj (Clynes i Kline, 1960: 27, 74). Različite koncepcije kiborga, kao sučelja ljudskog tijela i svijesti i tehnologije, mogu se koristiti u smislu »obnavljanja« izgubljenih funkcija organizma $\mathrm{i} / \mathrm{ili}$ nadomještanja izgubljenih organa i dijelova tijela, zatim $u$ smislu »normaliziranja« nekog organizma, u smislu »preoblikovanja« koje izravno smjera poslijeljudskom i u smislu »pojačavanja« postojećih ljudskih sposobnosti (Gray, Mentor i Figueroa-Sarriera, 1995: 3). »Dijete po narudžbi« predstavlja koncepciju koja proizlazi iz razvoja suvremene biogenetike i biotehnologije u smislu mogućnosti određivanja osnovnih genskih karakteristika djeteta u samom začetku njegova života. Sam pojam preuzimamo od Fukuyame koji se koristi i drugim pojmom - »djeca po mjeri« (Fukuyama, 2003: 104, 102). U literaturi se koriste i pojmovi »dizajnirana djeca« (Harris, 2007: 143), te »djeca izbora« (Robertson, 1994), gdje se ta koncepcija suprotstavlja »djeci slučaja« (Hughes, 2004: 135). Ra- 
zvoj »djeteta po narudžbi« može uključivati različite biogenetičke i biomedicinske postupke, od različitih postupaka umjetne oplodnje do genetičkog skeniranja embrija ili fetusa (Robertson, 1994: 10) i »poboljšanja slučajne kombinacije gena" (Harris, 2007: 143).

Određivanje koncepcija »poslijeljudskog« i »posthumanizma« izlažemo u drugom dijelu rada. Uvodno tek možemo istaknuti kako se unutar tih koncepcija ljudski život promatra kao »objekt tehnološkog dizajna, kombinacija informacija i biotehnologije« (Best i Kellner, 2001: 198).

Rad, uz uvod i zaključak, sadržava četiri dijela. Nakon ovoga prvog i uvodnog dijela u kojem dajemo pregled sadržaja rada i kratka određenja osnovnih pojmova i koncepcija, u drugom dijelu rada ukratko izlažemo osnovna teorijska stajališta "posthumanizma« i osnovne teorijske pristupe koncepcija poslijeljudskog života, s posebnim naglaskom na sučeljavanje suprotstavljenih stajališta »transhumanizma« i »biokonzervativizma«. Treći dio rada sadržava kratke metodološke napomene o uzorku i načinu provedbe empirijskog istraživanja na čijim se rezultatima temelji ovaj rad. Također navodimo opću hipotezu i nekoliko radnih hipoteza. U četvrtom dijelu rada dajemo pregled osnovnih rezultata empirijskog istraživanja i usporedbu tih rezultata s rezultatima koji su dobiveni istraživanjem iz 2005. godine na prigodnom uzorku studenata pet fakulteta Sveučilišta u Zagrebu. Peti dio rada sadržava analizu koncepcija poslijeljudskog života u sociokulturnom kontekstu suvremenoga hrvatskog društva. U zaključnom dijelu analiziramo dobivene rezultate, kako u užem kontekstu postavljenih hipoteza, tako i u širem kontekstu razvoja biotehnologije i bioznanosti.

\section{2. „Posthumanizam» $\mathrm{i}$ teorijski pristupi koncepcijama poslije- ljudskog života}

Cjelokupna povijest ljudskih društava, između ostalog, obilježena je idejnim konstruktima, teorijama i praksama koje su smjerale uspostavi kriterija određivanja ljudskoga. Različita razdoblja razvoja društva nudila su, a često i nametala, različite kriterije u tom smislu. Unutar tih okvira »posthumanizam« se pojavljuje kao teorija i praksa određivanja ljudskoga kroz biotehnološko posredovanje. Ostavljajući kriterije prirode, mita, religije, evolucije, kulture, politike i nacije, "posthumanizam«, u određivanju razlika »ljudskog « i »poslijeljudskog«, preuzima kriterije tehnologije i znanosti. Razlikovanje »ljudskog« $\mathrm{i} »$ poslijeljudskog« uglavnom se temelji na razlikovanju biološkog i poslijebiološkoga inteligentnog života. »Ljudsko« (biološko) se, uglavnom pod utjecajem prosvjetiteljstva, povezuje s racionalnošću, slo- 
bodnom voljom, autonomijom i samosviješću kao osnovama ljudskog identiteta. S druge strane, "poslijeljudsko« (poslijebiološko) konstruira se kroz informacijske obrasce unutar biološkog okvira (tijela) (Hayles, 2006: 160). »Posthumanizam« se u tom smislu pojavljuje kao vjera u umjetno poboljšanu evoluciju, koja se temelji na ontološkoj promjeni ne samo prirode ljudskih društava nego i samih ljudskih tijela (Terranova, 2000: 270). No u općem smislu ideja »posthumanizma« kao ideja nadilaženja modernog humanizma može se pronaći u klasičnim teorijskim sustavima, primjerice u Marxovoj kritici lažne univerzalnosti građanske moralnosti, Nietzscheovoj kritici kršćanske etike, demokracije i socijalizma te Heideggerovoj kritici metafizike (Feenberg, 2000: 152). U suvremenim teorijskim pristupima »posthumanizam« se kao teorijski pojam razvija unutar strukturalizma i poststrukturalizma, gdje se humanizam odbacuje kao filozofska iluzija, a suvereni subjekt zamjenjuje sustavom jezika i želja (Lévi-Strauss, Barthes, Foucault, Lacan), socioekonomskim strukturama (Althusser), te medijima i tehnologijom (Baudrillard) (Best i Kellner, 2001: 181). Tako je primjerice Foucaultov navod iz predgovora Riječi i stvari o tome da je »utješno [...] razmišljati kako je čovjek tek nedavno otkriće, figura niti dva stoljeća stara, novi nabor u našoj spoznaji, i da će nanovo nestati čim naša spoznaja otkrije novi oblik« (Foucault, 2002: xxv), postao »općim mjestom« većine teorijskih analiza »posthumanizma«.

»Posthumanizam《 se pojavljuje i »prije« i »poslije« humanizma. »Prije« u smislu ukorijenjenosti ljudskog bića ne samo u biološkom svijetu, nego i u tehnološkom svijetu (protetska koevolucija ljudi i tehnike), a »poslije« u smislu povijesnog razdoblja temeljenog na decentralizaciji ljudskog bića (Wolfe, 2010: xv). Neki autori navode kako "posthumanizam « ne označava ukidanje humanizma, nego prije njegovu unutrašnju kritiku (Badmington, 2003: 22). U općem smislu »posthumanizam« se može podijeliti na tri pristupa: prvi, koji proizlazi iz kritičke teorije koncepcija humanizma i ljudskog subjekta; drugi, koji analizira razvoj znanosti i tehnologije i utjecaj tog razvoja na ljudsko tijelo; treći, koji je povezan $\mathrm{s}$ razvojem reproduktivnih tehnologija, biotehnologije i genetike (Lister i dr., 2009: 282).

»Posthumanizam« tematizira poslijeljudski život, a razvoj koncepcija poslijeljudskog života temelji se na osnovnoj idejnoj konstrukciji kiborga, odnosno na zamjeni promjena »vanjskog okoliša« (priroda, društvo, planet) promjenama »unutrašnjeg okoliša« (ljudsko tijelo i svijest). Prema N. Katherine Hayles poslijeljudsko stajalište temelji se na nekoliko pretpo- 
stavki: prvo, ističe se važnost informacijskih obrazaca ispred materijalnosti, te se bioutjelovljenje (život) promatra kao povijesna slučajnost, a ne neumitnost života (evolucije); drugo, samosvijest se promatra kao »usputna pojava« evolucije, a ne kao temelj ljudskog identiteta; treće, tijelo se predstavlja kao izvorna proteza kojom su ljudi naučili upravljati, a zamjena tijela nadomjescima predstavlja nastavak procesa koji je počeo davno prije razvoja ljudske vrste; i četvrto, ljudsko tijelo se oblikuje tako da može biti »bešavno« spojeno s »inteligentnim strojem«. Za poslijeljudsko stajalište nema bitne razlike između egzistencije ljudskog tijela i računalne simulacije, kibernetičkog mehanizma i bioorganizma, svrhovitosti robota i ljudskih ciljeva (Hayles, 1999: 2-3). Poslijeljudsko stanje temelji se na mehanizaciji ljudskog i tehnologizaciji prirodnog, na sve nejasnijim granicama vrsta $\mathrm{i}$ samog ljudskog tijela, te na stvaranju novih društvenih i osobnih svjetova (Graham, 2004: 15). »Ako 'ljudsku bit predstavlja sloboda od volje drugih', poslijeljudsko je 'poslije' ne zbog toga što bi nužno bilo neslobodno, već zbog toga što više ne postoji način identificiranja volje pojedinačnog jastva koja se može jasno razlikovati od volje drugih« (Hayles, 1999: 4). Oblikovanje poslijeljudskog temelji se na dvije ključne dijalektike: prisutnosti/ odsutnosti i obrasca/slučajnosti, unutar kojih se javljaju koncepti materijalnosti, informacije, mutacije i hiperrealnosti (Hayles, 1999: 247-250).

Jedan od osnovnih ciljeva »posthumanizma« u općem smislu jest oslobađanje od ograničenosti ljudskih tijela i radikalno produženje života (Horrobin, 2006: 280), koje bi trebalo voditi ka konačnoj »pobjedi nad smrću«. U razmatranju procesa bitnog produženja ljudskog života (u konačnici usmjerenih $\mathrm{k}$ »besmrtnosti«) ističu se najmanje dva moguća puta: prvi, zamjena određenih »dotrajalih« dijelova tijela (organa, udova), proizašla iz potrebe ili želje, novim dijelovima (koji mogu biti biološke ili nebiološke »replike«), te drugi, potpuno uranjanje u virtualne svjetove (Seidel, 2009: 45). »Posthumanizam« predstavlja moralnost koja više nije utemeljena na konačnosti ljudskog bića (Le Breton, 2004: 3) i time otvara niz moralnih i socijalnih pitanja i prijepora.

U analizi prijepora oko tehnološkog »poboljšavanja« ljudske vrste nameću se dva suprotstavljena stajališta. Prvo stajalište, koje se naziva »transhumanizam«, zagovara »tehnološka poboljšanja« te smatra da se sadašnja ljudska priroda može poboljšati korištenjem primijenjenih znanosti (u smislu produljenja životne dobi, poboljšanja zdravlja te proširenja intelektualnih i fizičkih sposobnosti). Drugo stajalište, tzv. »biokonzervativizam«, protivi se mogućnostima tehnoznanstvene intervencije u ljudsku 
prirodu, te ističe kako bi »tehnologija poboljšavanja ljudi« mogla voditi »dehumanizaciji«. Prvo stajalište većim dijelom proizlazi iz sekularnog humanizma i prosvjetiteljstva, dok se drugo stajalište djelomice temelji na sekularnom humanizmu, ali i na religijskim učenjima (Bostrom, 2005: 202-203). Za »transhumanizam« tehnologija predstavlja krajnje sredstvo ostvarivanja veće kontrole nad prirodnim svijetom, ljudskim tijelom i samom evolucijom. Autori koji zagovaraju »transhumanistička« stajališta ističu kako će »biotehnološka modifikacija ljudske prirode predstavljati, ako ništa drugo, jedno poboljšanje naše osnovne humanosti, te u prilog tomu nude dva blisko povezana argumenta; prvi, poboljšanje će unaprijediti našu humanost, i drugi, poboljšanje neće degradirati našu humanost« (Wilson i Haslam, 2009: 251). Prema »transhumanističkim« pogledima tehnologije »ljudskog poboljšavanja« trebale bi biti dostupne svima u svrhu ostvarivanja »morfološke slobode« svih pojedinaca i »reproduktivne slobode« svih koji žele biti roditelji (Bostrom, 2005: 203). »Uskoro stvaranje djece neće zahtijevati očeve, a majke rodilje će razvojem umjetnih maternica postati jednom od opcija. Homoseksualni parovi imat će biološku djecu genski povezanu s obama partnerima« (Hughes, 2004: 21). Jedno od »klasičnih« stajališta »transhumanizma« jest da su »ljudi općenito sretniji kad imaju veću kontrolu nad svojim životima, a tehnologija i demokracija su dva ključna puta po kojima možemo ostvariti veću kontrolu nad svojim životima« (Hughes, 2004: 8). Umjesto dugotrajnih procesa socijalizacije, obrazovanja, pružanja zdravstvenih usluga i socijalne skrbi, »transhumanizam« predlaže »proizvodnju« veće inteligencije, većih kognitivnih mogućnosti i boljeg zdravlja kroz tehnologije »ljudskog poboljšavanja« (Harris, 2007: 2). Jedan od poznatijih zagovornika »transhumanizma« je i australski konceptualni umjetnik Stelarc koji ističe kako je ljudsko tijelo zastarjela kategorija. Za Stelarca, tehnološko »koloniziranje« tijela predstavlja kraj evolucije. Primjena biotehnologije otvara mogućnosti ukidanja rađanja (izvantjelesna oplodnja i njega fetusa) i smrti (zamjena »dotrajalih« dijelova tijela). S obzirom na sve nepovoljnije životne uvjete u prirodi, da bi se prilagodilo, tijelo mora postati besmrtnim (Stelarc, 2000: 561-567). Paradigmatski prikaz »transhumanizma« daje James Hughes koji ističe kako će nam »u 21. stoljeću transhumane tehnologije omogućiti dulji život te da budemo pametniji i da imamo veću kontrolu nad vlastitim emocijama i tijelima. I ne samo to. Također će nam omogućiti kloniranje, miješanje ljudske i životinjske DNA i genetičku modifikaciju naših tijela u estetske svrhe. Ugradit ćemo računala u svoja tijela i umove, te simulirati ljudske mozgove u raču- 
nalima. Svakim će danom naši sugrađani ubrzano postajati sve čudnijima, stoga ćemo trebati nove kategorije i novo razumijevanje demokracije kako bismo stvorili novi smisao svijeta« (Hughes, 2004: 77).

Spomenuta stajališta pretrpjela su brojne kritike. Tako primjerice Francis Fukuyama ističe da »najvažnija opasnost od suvremene biotehnologije leži u njezinoj mogućnosti izmjene ljudske naravi, čime bismo ušli u 'poslijeljudsku' fazu povijesti - to bi bio kraj čovjeka« (Fukuyama, 2003: 18). Fukuyama analizira mogućnosti i prijepore primjene suvremene biotehnologije i bioznanosti u nekoliko područja, a to su proučavanje mozga, neurofarmakologija i nadzor nad ponašanjem, produljivanje života i genetičko inženjerstvo. Pritom navodi kako će »prvi korak prema većem nadzoru roditelja nad genetskim sastavom svoje djece doći ne od genetskog inženjerstva nego s genetskim dijagnozom i pregledom zametka prije usađivanja. U budućnosti će možda postati redovit postupak da roditelji daju zametke na pregled za mnoge bolesti, pa bi samo zametci s 'pravim' genima bili usađeni u majčinu utrobu, a ostali odstranjeni« (Fukuyama, 2003: 100). Za Fukuyamu krajni cilj suvremene biotehnologije i bioznanosti jest »dijete po mjeri« te mogućnosti dobivanja »djece po narudžbi« (Fukuyama, 2003: 102-107). S tim u vezi, pojavljuju se mogućnosti »utrke u genetskom naoružavanju djece« (Fukuyama, 2003: 126) čiju predigru već možemo pratiti kroz suvremene reforme obrazovnog sustava. Sličnu argumentaciju možemo naći i kod Leona Kassa koji navodi da »ako većina djece dobiva poboljšanje pamćenja ili stimulacijske droge, neuspjeh roditelja da svom djetetu to omogući može biti označen kao zanemarivanje djeteta « (Kass, 2003: 16). Fukuyaminu upozorenju da primjena biotehnologije, kako je primjerice zagovaraju »transhumanisti«, može »prouzročiti da na neki način izgubimo svoju ljudskost« i narušavanje »samog temelja ljudskog smisla za moral« (Fukuyama, 2003: 130-131), može se pridružiti Kassovo o prijetnji »dehumanizacije« i obećanju »superhumanizacije« (Kass, 2003: 10). Prema Kassu, stajalište da bi »ljudski život bio bolji bez smrti« u stvari označava stajalište da bi »ljudski život bio bolji kad bi bio nešto drugo od ljudskog« (Kass, 2001). U analizi mogućih negativnih posljedica primjene biotehnologije Kass priziva poznate oznake »igranja Boga« i »vrloga novog svijeta«, te ističe nužnost razlikovanja primjene biotehnologije u smislu »terapije« (koju smatra prihvatljivom) i »poboljšanja« (koju smatra neprihvatljivom) (Kass, 2003: 9-12). Za Kassa, "pokušaji pretvaranja ljudskog bića u nešto više mogu značiti dehumanizaciju« (Kass, 2003: 20). Slična stajališta zastupa i Jürgen Habermas koji navodi 
da primjena genske manipulacije kod djece »proizlazi iz brisanja granice između osoba i stvari« (Habermas, 2006: 24). Za Habermasa »[e]ksplozivna mješavina darvinizma i ideologije slobodne trgovine, koja se oko prijelaza iz 19. u 20. stoljeće pod svodom Pax britanicae raširila, čini se da se danas obnavlja u znaku globalnoga neoliberalizma. Više se doduše ne radi o socijaldarvinističkom prepoopćavanju biologijskih uvida, nego o istodobno medicinski i ekonomski osnovanom labavljenju 'socijalnomoralnih stega' biotehničkog napretka« (Habermas, 2006: 34). Kritiku razvoja suvremene biotehnologije i bioznanosti u spomenutom smislu možemo naći i kod Jeremyja Rifkina koji postavlja pitanje »[n]e bi li umjetno stvaranje života moglo nagovijestiti kraj prirodnog svijeta?« (Rifkin, 1999: 15). Rifkin upozorava da bi $»[n]$ ovorođenčad 'po mjeri' mogla utrti put nastanku eugeničke civilizacije u dvadesetprvom stoljeću « (Rifkin, 1999: 21) te kako »[m]ogućnost stvaranja novoga eugeničkog čovjeka i žene više nije san ludih političkih demagoga nego potrošačka opcija u bliskoj budućnosti i silno unosno komercijalno tržište« (Rifkin, 1999: 149). Kao i drugi autori koji kritički analiziraju razvoj biotehnologije, i posebice njegovu aktualnu i potencijalnu primjenu, i Rifkin upozorava da bi on mogao dovesti do gubitka »ono[ga] što smo tako silno željeli obogatiti«, a to je »naša ljudskost« (Rifkin, 1999: 217). Nick Bostrom u općem smislu navodi tri tipa straha koji su povezani s razvojem poslijeljudskih oblika života: prvi označava strah da sam proces "posthumanizacije« označava svojevrsnu degradaciju ljudskoga; drugi označava strah da bi poslijeljudski oblici života mogli predstavljati prijetnju »običnim« ljudima; i treći, da razvoj poslijeljudskih oblika života otvara mogućnosti nastanka »natprirodnih« (»superprirodnih«) bića (Bostrom, 2005: 204). Na kraju ovog teorijskog dijela dajemo sažeti shematski prikaz osnovnih pretpostavki navedenih suprotstavljenih stajališta.

\section{Shema 1. Sažetak osnovnih pretpostavki »pro« $\mathbf{i}$ »kontra» biotehnološke promjene ljudskog}

\begin{tabular}{|l|l|}
\hline $\begin{array}{l}\text { Zagovaratelji biotehnološke promjene } \\
\text { ljudskog }\end{array}$ & $\begin{array}{l}\text { Protivnici biotehnološke promjene } \\
\text { ljudskog }\end{array}$ \\
\hline $\begin{array}{l}\text { Ne postoji ljudska bit (ljudska priroda } \\
\text { je dinamična i stalno se razvija) }\end{array}$ & $\begin{array}{l}\text { Postoji ljudska bit (ona je dana i } \\
\text { strogo određena) }\end{array}$ \\
\hline $\begin{array}{l}\text { Naglasak na nesuštinskim kvalitetama } \\
\text { (npr. inteligencija, samokontrola) }\end{array}$ & $\begin{array}{l}\text { Naglasak na suštinskim kvalitetama } \\
\text { (npr. emocije, toplina, djelovanje) }\end{array}$ \\
\hline $\begin{array}{l}\text { Naglasak na dijelovima jastva »iznad } \\
\text { prirode«: ljudska jedinstvenost }\end{array}$ & $\begin{array}{l}\text { Naglasak na dijelovima jastva »u } \\
\text { prirodi«: ljudska priroda }\end{array}$ \\
\hline
\end{tabular}




\begin{tabular}{|l|l|}
\hline $\begin{array}{l}\text { Kvalitete ljudske prirode kao } \\
\text { modularni dijelovi koji zasebno mogu } \\
\text { biti poboljšani }\end{array}$ & $\begin{array}{l}\text { Naglasak na nedjeljivosti i očuvanju } \\
\text { »cjeline« ljudske prirode }\end{array}$ \\
\hline $\begin{array}{l}\text { Odbijanje »prirodnog« kao kriterija } \\
\text { za normativno određivanje dobrog i } \\
\text { ispravnog }\end{array}$ & $\begin{array}{l}\text { Zaštita »prirodnog« kao kriterija za } \\
\text { normativno određivanje dobrog i } \\
\text { ispravnog }\end{array}$ \\
\hline $\begin{array}{l}\text { Privilegiranost racionalne spoznaje } \\
\text { (inteligencija, misao, »djelatna« } \\
\text { svijest) }\end{array}$ & $\begin{array}{l}\text { Privilegiranost neracionalne spoznaje } \\
\text { (emocije, težnje, »iskustvena« svijest) }\end{array}$ \\
\hline $\begin{array}{l}\text { Tehnologije poboljšavanja ne utječu } \\
\text { na kvalitete koje su ključne za osobni } \\
\text { identitet }\end{array}$ & $\begin{array}{l}\text { Tehnologije poboljšavanja utječu na } \\
\text { kvalitete koje su ključne za osobni } \\
\text { identitet }\end{array}$ \\
\hline $\begin{array}{l}\text { Biotehnološke promjene predstavljaju } \\
\text { dobitak ljudskosti }\end{array}$ & $\begin{array}{l}\text { Biotehnološke promjene predstavljaju } \\
\text { gubitak ljudskosti }\end{array}$ \\
\hline $\begin{array}{l}\text { Biotehnološke promjene će } \\
\text { "proizvesti superljudska bića« }\end{array}$ & $\begin{array}{l}\text { Biotehnološke promjene će } \\
\text { »proizvesti dehumanizirana bića« }\end{array}$ \\
\hline
\end{tabular}

Izvor: Wilson i Haslam, 2009: 256

\section{Metodološke napomene}

\subsection{Uzorak}

Rad se temelji na analizi rezultata empirijskog istraživanja provedenog u sklopu projekta »Supsidijarnost u hrvatskom društvu« (203-19415330732) pod vodstvom prof. dr. sc. Stjepana Balobana. Istraživanje je provedeno usmenom anketom tijekom prosinca 2009. godine. Realiziranim je uzorkom obuhvaćeno točno 1000 sudionika iz 70 naselja odnosno 100 različitih lokacija (sample points). Istraživanje je provedeno na probabilistički izabranom, višeetapno stratificiranom uzorku punoljetnog stanovništva Hrvatske. Teritorijalni plan uzorka temeljen je na administrativnoj podjeli na županije te podjeli na razmjerno homogene regije, izdvojene faktorskom i klasterskom analizom više od 30 relevantnih demografskih pokazatelja iz popisa stanovništva. Izbor jedinica (naselja) unutar regija i županija proveden je metodom slučajnog izbora bez povrata, pri čemu je svaka jedinica imala vjerojatnost izbora proporcionalnu broju stanovnika s kojim sudjeluje u nadređenoj stratifikacijskoj jedinici uzorka. Adrese kućanstava u kojima je provedeno anketiranje izabrane su sistematski $\mathrm{s}$ popisa adresa na pojedinoj lokaciji, a izbor ispitanika unutar kućanstava izvršen je metodom Troldahla i Cartera. Usporedba strukture realiziranog uzorka i populacije, s obzirom na osnovne sociodemografske karakteri- 
stike, pokazala je odstupanja u odnosu na stupanj obrazovanja. S tim u skladu, podaci su ponderirani prema kriteriju obrazovanja (v. u: Rihtar i Franc, 2011). Sve analize izvršene su na ponderiranom uzorku $(\mathrm{N}=$ 1387). Struktura uzorka prema spolu, dobi i stupnju obrazovanja je sljedeća:

Tablica 1. Struktura uzorka prema spolu, dobi i stupnju obrazovanja

\begin{tabular}{|l|r|}
\hline & \% \\
\hline Spol & \\
\hline ženski & 51,2 \\
\hline muški & 48,8 \\
\hline Dob & \\
\hline do 30 godina & 21,1 \\
\hline $31-40$ & 17,3 \\
\hline $41-50$ & 19,4 \\
\hline $51-60$ & 19,2 \\
\hline 61 i više godina & 23,0 \\
\hline Stupanj obrazovanja & \\
\hline bez škole & 3,0 \\
\hline $1-4$ razreda osnovne škole & 7,2 \\
\hline $5-8$ razreda osnovne škole & 29,8 \\
\hline $\begin{array}{l}\text { srednja škola - dvogodišnja i } \\
\text { trogodišnja }\end{array}$ & 18,4 \\
\hline srednja škola - četverogodišnja & 26,6 \\
\hline viša škola & 6,5 \\
\hline visoka, fakultet & 8,5 \\
\hline
\end{tabular}

\subsection{Mjerni instrumenti}

Za empirijsko istraživanje koncepcija poslijeljudskog života konstruiran je instrument sastavljen od šest tvrdnji koje sadržajno obuhvaćaju dvije koncepcije proizišle iz razvoja kibernetike i biotehnologije, a to su koncepcije »kiborga« i »djeteta po narudžbi«. Dobiveni rezultati uspoređuju se s rezultatima istraživanja koje je provedeno 2005. godine na prigodnom uzorku studenata pet fakulteta Sveučilišta u Zagrebu $(\mathrm{N}=492)$. Navedene koncepcije analiziraju se s obzirom na osnovne sociodemografske karakteristike ispitanika (spolna, dobna i obrazovna struktura, stupanj obrazovanja oca i majke, mjesečni prihodi), političke orijentacije i osnovne religijske karak- 
teristike ispitanika (institucionalna religijska praksa, religioznost, uvjerenje o postojanju Boga). ${ }^{1} \mathrm{U}$ istraživanju političkih orijentacija ispitanika te njihovih osnovnih religijskih karakteristika koristila su se pitanja zatvorenog tipa gdje se tražila samoprocjena ispitanika. ${ }^{2}$

\subsection{Hipoteze}

Osnovni je cilj rada prezentacija i analiza rezultata empirijskog istraživanja koncepcija poslijeljudskog života u suvremenom hrvatskom društvu.

Opća hipoteza:

U radu polazimo od opće hipoteze da analizirane koncepcije poslijeljudskog života neće biti prihvaćene, odnosno da će pojedine tvrdnje, koje predstavljaju sadržaj tih koncepcija, biti prihvaćene tek u manjoj mjeri. Opću hipotezu temeljimo na rezultatima dosadašnjih teorijskih i empirijskih istraživanja koji ukazuju da u suvremenom hrvatskom društvu i dalje prevladavaju tradicionalna obilježja, u općem društvenom, kulturnom i religijskom smislu (Cifrić, 2003; Nikodem, 2004b; Marinović Jerolimov, 2005; Baloban, 2005; Črpić i Zrinščak, 2010).

Radne hipoteze:

$\mathrm{S}$ obzirom na naznačene analize $\mathrm{u}$ radu postavljamo i sljedeće radne hipoteze:

1. Ispitanici mlađe životne dobi bit će skloniji prihvaćanju koncepcija poslijeljudskog života, za razliku od ispitanika starije životne dobi;

\footnotetext{
${ }^{1}$ Cjeloviti prikaz rezultata empirijskog istraživanja provedenog u sklopu projekta »Supsidijarnost u hrvatskom društvu« (203-1941533-0732) objavljen je u časopisu Bogoslovska smotra (god. 81, 2011, br. 4). Distribucije postotaka na tim pitanjima mogu se naći u: Črpić i Mravunac, 2011.

${ }^{2}$ Političke orijentacije: »U političkim pitanjima ponekad govore o 'ljevici, centru i desnici'. Kako biste u tom smislu označili svoje uvjerenje? U odgovorima koristite ocjene od 1 do 10 , pri čemu 1 označuje krajnje lijevu, a 10 krajnje desnu političku orijentaciju«. Za potrebe analize podaci su rekodirani na sljedeći način: 1-3 = lijevo; 4-7 = centar; 8-10 $=$ desno. Samoprocjena religioznosti: „Neovisno o tome idete li u crkvu ili ne, biste li se nazvali: 1. Religioznom osobom; 2. Nereligioznom osobom; 3. Uvjerenim ateistom; 4. Agnostikom; 5. Ne znam; 6. Nema odgovora«. Uvjerenje o postojanju Boga: »Koja se od ovih tvrdnji najviše slaže s Vašim uvjerenjima: 1. Ne mislim da postoji neka vrsta duha, Bog ili životna sila; 2. Ne znam što da mislim; 3. Postoji neka vrsta duha ili životne sile; 4. Postoji osobni Bog (Bog - osoba); 5. Ne znam; 6. Nema odgovora«. U analizi su isključeni oni ispitanici koji na ta pitanja nisu dali odgovor ili su odgovorili »Ne znam«. Institucionalna religijska praksa: »Osim vjenčanja, pogreba i krštenja, koliko često pohađate vjerske obrede u posljednje vrijeme: 1 . Nikada, gotovo nikada; 2 . Rjeđe od jednom godišnje; 3. Jednom godišnje; 4. Samo za vjerske blagdane; 5. Jednom mjesečno; 6. Jednom tjedno; 7. Više nego jednom tjedno«.
} 
2. Ispitanici s višim stupnjem obrazovanja bit će skloniji prihvaćanju koncepcija poslijeljudskog života, za razliku od ispitanika s nižim stupnjem obrazovanja;

3. Ispitanici politički »lijevo« orijentirani bit će skloniji prihvaćanju koncepcija poslijeljudskog života, za razliku od ispitanika koji su politički »desno« orijentirani;

4. Ispitanici koji se smatraju religioznima, koji vjeruju u postojanje osobnog Boga i koji tjedno odlaze na misu bit će skloniji odbijanju spomenutih koncepcija, za razliku od onih koji se smatraju nereligioznima, uvjerenim ateistima i agnosticima te uopće ne idu na misu.

\subsection{Metode}

$\mathrm{U}$ analizi rezultata empirijskog istraživanja koristimo distribuciju postotaka, faktorsku analizu (komponentni model, varimax rotacija, GK kriterij redukcije dimenzionalnosti), korelacijsku analizu (Pearsonov koeficijent) i analizu varijance. Podaci su obrađeni u programskom paketu IBM SPSS 19.1.

\section{Pregled osnovnih rezultata istraživanja}

Kako je spomenuto, koncepcije poslijeljudskog života koje analiziramo u ovom radu su »kiborg« $\mathrm{i} »$ dijete po narudžbi«. Te koncepcije proizlaze iz razvoja kibernetike i biotehnologije i predstavljaju dva, uvjetno rečeno, nova »poretka društvenosti« - »tehnodruštvenosti« i »biodruštvenosti« (Escobar, 2000: 57). U Tablici 2 prikazani su rezultati na tvrdnjama koje sadržajno obuhvaćaju te koncepcije. Najveći postotak slaganja $(33,3 \%)$ dobiven je na prvoj tvrdnji. S druge strane, najniži postotak slaganja $(8,8 \%)$ dobiven je na drugoj tvrdnji. Obje tvrdnje proizlaze iz sociokulturnog konteksta radikalnog neoliberalizma (prije svega naglasak na pravima pojedinaca) i dominirajuće potrošačke kulture (naglasak na slobodi izbora). Jedan od ključnih argumenata za stvaranje »djeteta po narudžbi« jest mogućnost uklanjanja genskih predispozicija za određene bolesti. Primjer takvog razmišljanja možemo naći kod Harrisa koji postavlja pitanja »ako nije moralno loše željeti zdravo dijete, zar bi bilo pogrešno, ako imamo tu moć, ostvariti tu želju?« te nastavlja »ako dizajnirana djeca predstavljaju poboljšanje slučajne kombinacije gena, ili daju veću pouzdanost u tom smislu, zar bi bilo etično ne biti dizajner?« (Harris, 2007: 89, 143). Sličnu argumentaciju Harris nudi i u pitanju odabira spola djeteta koje označava »moralno neutralnim«, a »u nedostatku moralnih razloga za preferenciju, postoji pretpostavka koja ide u prilog slobodnom izboru« i dodaje »boja kose, očiju, spol jesu ili nisu 
važni. Ako nisu važni, zašto ne dopustiti ljudima da ih biraju? Ako su pak važni, zar bi bilo ispravno prepustiti tako važne stvari slučaju?« (Harris, 2007: 147, 146).

Tablica 2. Prihvaćenost koncepcija poslijeljudskog života u hrvatskom društvu

\begin{tabular}{|c|c|c|c|c|c|}
\hline Tvrdnja (\%) & 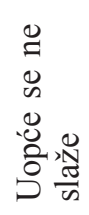 &  & 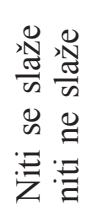 & 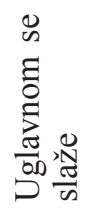 & 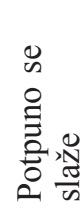 \\
\hline $\begin{array}{l}\text { Stvaranje djeteta po narudžbi } \\
\text { uz pomoć genske tehnologije } \\
\text { privatna je stvar pojedinca. }\end{array}$ & 36,2 & 12,5 & 17,0 & 18,4 & 14,9 \\
\hline $\begin{array}{l}\text { Odabir spola djeteta radi } \\
\text { zadovoljenja želje roditelja } \\
\text { moralno je opravdan. }\end{array}$ & 55,7 & 17,1 & 17,1 & 6,2 & 2,6 \\
\hline $\begin{array}{l}\text { Ljudsko tijelo kakvo } \\
\text { poznajemo nije konačan i } \\
\text { nepromjenjiv oblik, nego } \\
\text { jedan od mogućih oblika na } \\
\text { putu ljudske evolucije. }\end{array}$ & 29,3 & 11,7 & 31,7 & 17,7 & 8,3 \\
\hline $\begin{array}{l}\text { Ukidanje procesa starenja } \\
\text { kod ljudi trebao bi biti } \\
\text { jedan od najvažnijih ciljeva } \\
\text { tehnologijsko-znanstvenog } \\
\text { razvoja. }\end{array}$ & 47,4 & 19,4 & 20,7 & 7,8 & 2,7 \\
\hline $\begin{array}{l}\text { Postoji bitna sličnost između } \\
\text { rada ljudskog mozga i rada } \\
\text { računala. }\end{array}$ & 29,7 & 15,5 & 26,7 & 19,0 & 7,7 \\
\hline $\begin{array}{l}\text { Ljudsko biće je prije skup } \\
\text { informacija nego spoj mesa, } \\
\text { krvi, vode, neurona i sl. }\end{array}$ & 37,3 & 17,3 & 31,5 & 9,2 & 2,9 \\
\hline
\end{tabular}

Otprilike četvrtina ispitanika (26,0\%) slaže se s trećom tvrdnjom koja predstavlja opću postavku kibernetičkih i biotehnoloških usmjerenja prema ljudskom. Prema stajalištima »transhumanizma« ljudska evolucija je »upala u slijepu ulicu«, što zahtijeva biotehnološko posredovanje u »traženju izlaza« u »poboljšanu evoluciju« (Harris, 2007). Radikalna stajališta i prakse u tom smislu možemo naći primjerice kod Stelarca koji ističe kako je ljudsko tijelo »zastarjelo« $\mathrm{i} » n e$ predstavlja efikasnu i dugovječnu strukturu [...] stoga više nije smisleno promatrati tijelo kao središte psi- 
hičkog i društvenog, nego prije kao strukturu za nadgledanje i modificiranje; ne kao subjekt, nego kao objekt - ne kao objekt želja, nego kao objekt za dizajniranje« (Stelarc, 2000: 561-562). Nizak postotak slaganja dobiven je na četvrtoj tvrdnji $(10,5 \%)$ koja pripada sociokulturnom kontekstu »postmortalnog društva « u kojem starost, i sama smrt, predstavljaju bolest koja se može izbjeći primjenom kontrolnih i sigurnosnih postupaka biomedicine, odnosno »regenerativne medicine« (Lafontaine, 2009: 54). Posljednje dvije tvrdnje izravno proizlaze iz teorije kibernetike Norberta Wienera. Naime, teza njegove knjige iz 1954. godine je »da između fizičkog djelovanja živog pojedinca i rada nekih novijih komunikacijskih strojeva postoji potpuni identitet u smislu nastojanja kontrole entropije putem povratne sprege« (Wiener, 1964: 42). Za Wienera »između živčanog sustava i automatskog stroja postoji osnovna sličnost u tome što [...] donose odluke na temelju prošlih odluka« (Wiener, 1964: 50). Wiener ističe kako je ljudski organizam poruka jer $\gg[\mathrm{m}] \mathrm{i}$ ne predstavljamo građu koja se održava, nego strukture koje se ovjekovječuju. Struktura je poruka i može se prenijeti kao poruka« (Wiener, 1964: 123). Wienerove zamisli o prenošenju »strukture ljudskog tijela i ljudskog mozga« u neki dugotrajniji oblik, te isticanje kako se »fizički identitet pojedinca« ne temelji na materijalnom obliku, nego na unutrašnjim procesima, možemo naći i kod Hansa Moraveca. Razmatrajući mogućnosti da se tijek rada nekog računala može zaustaviti u nekom trenutku te prebaciti u obliku određenog programa u drugo računalo koje je fizički zaseban entitet od prvog, a da se u prebačenom procesu rada ništa ne promijeni, Moravec analogijom dolazi do ideje da bi se slično moglo izvesti i sa sadržajem ljudskog mozga. Moravec ističe mogućnosti prijenosa sadržaja ljudskog mozga, ne samo iz jednog u drugo tijelo, nego i iz tijela u računalo, ili neku drugu bazu podataka te navodi da se takvim zamislima suprotstavlja jedna zastarjelo stajalište koje on naziva »tijelo-identitet«, za razliku od suvremenog stajališta koje označava kao »obrazac-identitet«. Prvo stajalište pretpostavlja određivanje ljudskog identiteta »stvarima« koje pripadaju tijelu, iz čega proizlazi da je održavanje kontinuiteta tijela nužno za očuvanje individualnog identiteta. Drugo stajalište određuje »bit« ljudskog identiteta kao obrazac i proces koji se odvija u ljudskom tijelu i svijesti. Očuvanje tog procesa znači i očuvanje ljudskog identiteta, bez obzira na samo ljudsko tijelo (Moravec, 1988: 4-5, 116-117). S petom tvrdnjom slaže se otprilike četvrtina ispitanika (26,7\%), dok slaganje sa šestom tvrdnjom izražava tek $12,1 \%$ ispitanika. 
Usporedba ovdje dobivenih rezultata s rezultatima istraživanja na prigodnom uzorku studenata pet fakulteta Sveučilišta u Zagrebu (Nikodem, 2009: 114) pokazuje kako je razina prihvaćanja spomenutih tvrdnji uglavnom nešto viša kod studenata nego kod opće populacije, uz dvije iznimke. Naime, usporedba rezultata na prvoj tvrdnji pokazuje da je njezino prihvaćanje nešto više u općoj populaciji nego među studentima, a prihvaćanje treće tvrdnje znatno je više među studentima nego u općoj populaciji.

Tablica 3. Prihvaćenost koncepcija poslijeljudskog života - usporedba studenti i opća populacija

\begin{tabular}{|l|c|c|}
\hline Tvrdnja (\%) & $\begin{array}{c}\text { Studenti } \\
(2005, N=492)\end{array}$ & $\begin{array}{c}\text { Opća populacija } \\
(2009, N=1000)\end{array}$ \\
\hline $\begin{array}{l}\text { Stvaranje djeteta po narudžbi uz pomoć } \\
\text { genske tehnologije privatna je stvar } \\
\text { pojedinca. }\end{array}$ & 27,7 & 33,3 \\
\hline $\begin{array}{l}\text { Odabir spola djeteta radi zadovoljenja } \\
\text { želje roditelja moralno je opravdan. }\end{array}$ & 11,0 & 8,8 \\
\hline $\begin{array}{l}\text { Ljudsko tijelo kakvo poznajemo nije } \\
\text { konačan i nepromjenjiv oblik, nego } \\
\text { jedan od mogućih oblika na putu ljudske } \\
\text { evolucije. }\end{array}$ & 57,7 & 26,0 \\
\hline $\begin{array}{l}\text { Ukidanje procesa starenja kod ljudi } \\
\text { trebao bi biti jedan od najvažnijih } \\
\text { ciljeva tehnologijsko-znanstvenog } \\
\text { razvoja. }\end{array}$ & 12,2 & 10,5 \\
\hline $\begin{array}{l}\text { Postoji bitna sličnost između rada } \\
\text { ljudskog mozga i rada računala. }\end{array}$ & 34,8 & 26,7 \\
\hline $\begin{array}{l}\text { Ljudsko biće je prije skup informacija } \\
\text { nego spoj mesa, krvi, vode, neurona i sl. }\end{array}$ & 23,4 & 12,1 \\
\hline
\end{tabular}

Spomenute razlike su, iako ilustrativne, očekivane, ne samo zbog činjenice što su mladi općenito otvoreniji prema »novim stvarima« i skloniji liberalnijim shvaćanjima, nego i zbog toga što upravo ti mladi odrastaju u sociokulturnom kontekstu kojim, između ostalog, dominira razvoj biotehnologije i bioznanosti i njegova primjena u svakodnevnom životu. S tim u vezi, Frank Webster ističe da je jedna od ključnih karakteristika suvremenog Zapadnog svijeta dominacija dvomišljenja da se s jedne strane od individualnog života može učiniti što god se želi, odnosno da je ljudsko biće potpuno promjenjiva kategorija (od promjene izgleda, spola, dobi, do promjene svijesti), a s druge strane da je postojeći društveno-politički po- 
redak globalnog kapitalizma potpuno nepromjenjiva kategorija, odnosno da je konformizam jedino rješenje u tom smislu (Webster, 2002: 34).

\section{Koncepcije poslijeljudskog života u sociokulturnom kontekstu}

Stajališta »transhumanizma«, koja ističu prednosti kibernetičkih i biotehnoloških »intervencija u ljudsko«, uglavnom se temelje na neoliberalizmu i radikalnoj demokratskoj tradiciji (Hughes, 2004: 81). S druge strane, dio kritika »transhumanizma« dolazi iz religijskih tradicija, posebice katoličanstva. Stoga koncepcije poslijeljudskog života, osim u odnosu spram osnovnih sociodemografskih karakteristika, analiziramo i s obzirom na političke i religijske orijentacije ispitanika.

Faktorskom analizom, pod komponentnim modelom uz varimax rotaciju i GK kriterij redukcije dimenzionalnosti, na instrumentu »koncepcije poslijeljudskog života« dobivena su dva faktora. S obzirom na saturacije čestica prvi faktor smo nazvali »kiborg«, a drugi faktor smo nazvali »dijete po narudžbi«.

Tablica 4. Matrica varimax faktora - koncepcije poslijeljudskog života ${ }^{3}$

\begin{tabular}{|l|c|c|}
\hline & »Kiborg« & $\begin{array}{c}\text { »Dijete po } \\
\text { narudžbi« }\end{array}$ \\
\hline $\begin{array}{l}\text { Ljudsko biće je prije skup informacija nego } \\
\text { spoj mesa, krvi, vode, neurona i sl. }\end{array}$ &, 827 & \\
\hline $\begin{array}{l}\text { Postoji bitna sličnost između rada ljudskog } \\
\text { mozga i rada računala. }\end{array}$ &, 787 &, 617 \\
\hline $\begin{array}{l}\text { Ljudsko tijelo kakvo poznajemo nije konačan } \\
\text { i nepromjenjiv oblik, nego jedan od mogućih } \\
\text { oblika na putu ljudske evolucije. }\end{array}$ &, 662 \\
\hline $\begin{array}{l}\text { Stvaranje djeteta po narudžbi uz pomoć genske } \\
\text { tehnologije privatna je stvar pojedinca. }\end{array}$ &, 779 \\
\hline $\begin{array}{l}\text { Odabir spola djeteta radi zadovoljenja želje } \\
\text { roditelja moralno je opravdan. }\end{array}$ & & \\
\hline
\end{tabular}

Ekstrahirani faktori tumače $64,84 \%$ varijance.

Analiza dobivenih faktora s obzirom na osnovne sociodemografske karakteristike ispitanika (spolna, dobna i obrazovna struktura, stupanj obrazovanja oca i majke i mjesečni prihodi) pokazuje statistički značajne razli-

\footnotetext{
${ }^{3}$ Nakon inicijalne provedbe faktorske analize u sljedećem smo koraku, zbog zadovoljavanja kriterija jednostavne strukture, izostavili tvrdnju »ukidanje procesa starenja kod ljudi trebao bi biti jedan od najvažnijih ciljeva tehnologijsko-znanstvenog razvoja«.
} 
ke na obama faktorima s obzirom na dob ispitanika i stupanj obrazovanja majke ispitanika, te na jednom faktoru s obzirom na stupanj obrazovanja ispitanika i stupanj obrazovanja oca ispitanika. ${ }^{4}$

Ispitanici mlađe životne dobi (do 30 godina) skloniji su prihvaćanju analiziranih koncepcija poslijeljudskog života, za razliku od ispitanika srednje i starije životne dobi (»kiborg«), odnosno ispitanika starije životne dobi (»dijete po narudžbi«).

Tablica 5. Koncepcije poslijeljudskog života s obzirom na dobnu strukturu

\begin{tabular}{|c|c|c|c|c|c|}
\hline & & $M$ & $s$ & & Kontrast \\
\hline \multirow{5}{*}{ »Kiborg« } & do 30 god. & 0,2737 & 0,9377 & \multirow{5}{*}{$\begin{array}{c}F=10,246 \\
p<0,001\end{array}$} & \multirow{5}{*}{$\begin{array}{c}\text { do } 30 \text { god. } \\
>41 \mathrm{i} \text { više } \\
\text { god. }\end{array}$} \\
\hline & $31-40$ & 0,1261 & 1,030 & & \\
\hline & $41-50$ & $-0,0842$ & 0,9807 & & \\
\hline & $51-60$ & $-0,1919$ & 0,9957 & & \\
\hline & 61 i više god. & $-0,1167$ & 0,9933 & & \\
\hline \multirow{5}{*}{$\begin{array}{l}\text { »Dijete po } \\
\text { narudžbi« }\end{array}$} & do 30 god. & 0,1344 & 0,9943 & \multirow{5}{*}{$\begin{array}{c}F=3,413 \\
p<0,01\end{array}$} & \multirow{5}{*}{$\begin{array}{l}\text { do } 30 \text { god. } \\
>61 \mathrm{i} \text { više } \\
\text { god. }\end{array}$} \\
\hline & $31-40$ & $-0,0268$ & 0,9204 & & \\
\hline & $41-50$ & 0,0175 & 1,068 & & \\
\hline & $51-60$ & 0,0431 & 0,9719 & & \\
\hline & 61 i više god. & $-0,1571$ & 1,008 & & \\
\hline
\end{tabular}

Ispitanici s višim stupnjem obrazovanja (završena viša, visoka škola, fakultet itd.) skloniji su prihvaćanju koncepcije »kiborga«, za razliku od onih s nižim stupnjem obrazovanja (nezavršena i završena osnovna škola).

Tablica 6. Koncepcija »kiborga» s obzirom na stupanj obrazovanja ispitanika

\begin{tabular}{|l|c|c|c|c|}
\hline & $M$ & $s$ & & Kontrast \\
\cline { 1 - 3 } nezavršena i završena OŠ & $-0,1428$ & 0,9905 & \multirow{2}{*}{$F=9,804$} & \multirow{2}{*}{$1<3$} \\
\cline { 1 - 3 } srednja škola & 0,0754 & 1,006 & $p<0,001$ & \\
\cline { 1 - 3 } viša, visoka, fakultet & 0,1533 & 0,9628 & & \\
\cline { 1 - 3 }$d f$ (između skupina) $=2 ; d f$ (unutar skupina) $=1352$ &
\end{tabular}

Također, ispitanici čiji otac ima viši stupanj obrazovanja skloniji su prihvaćanju ove koncepcije, za razliku od ispitanika čiji otac ima niži ili srednji stupanj obrazovanja.

\footnotetext{
${ }^{4} \mathrm{~S}$ obzirom na spolnu strukturu i mjesečne prihode nije dobivena statistički značajna razlika na tim dvama faktorima te se ti rezultati u radu ne analiziraju.
} 
Tablica 7. Koncepcija »kiborga» s obzirom na stupanj obrazovanja oca ispitanika

\begin{tabular}{|c|c|c|c|c|}
\hline & $M$ & $s$ & & Kontrast \\
\hline nezavršena i završena OŠ & $-0,1731$ & 1,001 & \multirow{3}{*}{$\begin{array}{c}F=23,569 \\
p<0,001\end{array}$} & \multirow{3}{*}{$1,2<3$} \\
\hline srednja škola & 0,0839 & 0,9499 & & \\
\hline viša, visoka, fakultet & 0,3747 & 1,028 & & \\
\hline
\end{tabular}

Nadalje, ispitanici čija majka ima viši stupanj obrazovanja skloniji su prihvaćanju koncepcije »kiborga«, za razliku od ispitanika čija majka ima srednji ili niži stupanj obrazovanja. Ispitanici čija majka ima srednji stupanj obrazovanja skloniji su prihvaćanju koncepcije »dijete po narudžbi«, za razliku od onih čija majka ima niži stupanj obrazovanja.

Tablica 8. Koncepcije poslijeljudskog života s obzirom na stupanj obrazovanja majke ispitanika

\begin{tabular}{|c|c|c|c|c|c|}
\hline & & $M$ & $s$ & & Kontrast \\
\hline \multirow{3}{*}{$»$ Kiborg« } & $\begin{array}{l}\text { nezavršena i } \\
\text { završena OŠ }\end{array}$ & $-0,1165$ & 1,015 & \multirow{3}{*}{$\begin{array}{c}F=15,608 \\
p<0,001\end{array}$} & \multirow{3}{*}{$1,2<3$} \\
\hline & srednja škola & 0,0870 & 0,9451 & & \\
\hline & $\begin{array}{l}\text { viša, visoka, } \\
\text { fakultet }\end{array}$ & 0,3407 & 0,9870 & & \\
\hline \multirow{3}{*}{$\begin{array}{l}\text { »Dijete po } \\
\text { narudžbi« }\end{array}$} & $\begin{array}{l}\text { nezavršena i } \\
\text { završena OŠ }\end{array}$ & $-0,0687$ & 1,035 & \multirow{3}{*}{$\begin{array}{c}F=4,473 \\
p<0,02\end{array}$} & \multirow{3}{*}{$1<2$} \\
\hline & srednja škola & 0,1076 & 0,9513 & & \\
\hline & $\begin{array}{l}\text { viša, visoka, } \\
\text { fakultet }\end{array}$ & 0,0260 & 0,9306 & & \\
\hline
\end{tabular}

Analiza koncepcija poslijeljudskog života s obzirom na političke orijentacije ispitanika pokazuje da su politički »lijevo« orijentirani ispitanici skloniji prihvaćanju navedenih koncepcija.

Tablica 9. Koncepcije poslijeljudskog života s obzirom na političke orijentacije ispitanika

\begin{tabular}{|c|c|c|c|c|c|}
\hline & & $M$ & $s$ & & Kontrast \\
\hline \multirow{3}{*}{$»$ Kiborg« } & »lijevo« & 0,1614 & 0,9600 & \multirow{3}{*}{$\begin{array}{c}F=4,294 \\
p<0,02\end{array}$} & \multirow{3}{*}{$1>2$} \\
\hline & »centar« & $-0,0457$ & 1,012 & & \\
\hline & »desno« & $-0,0484$ & 1,008 & & \\
\hline
\end{tabular}




\begin{tabular}{|c|c|c|c|c|c|}
\hline \multirow{3}{*}{$\begin{array}{l}» \text { Dijete po } \\
\text { narudžbi« }\end{array}$} & »lijevo« & 0,0727 & 0,9869 & \multirow{3}{*}{$\begin{array}{c}F=3,971 \\
p<0,02\end{array}$} & \multirow{3}{*}{$1>3$} \\
\hline & »centar« & $-0,0005$ & 0,9932 & & \\
\hline & »desno« & $-0,1752$ & 0,9828 & & \\
\hline
\end{tabular}

U nastavku analiziramo spomenute koncepcije s obzirom na osnovne religijske karakteristike ispitanika kao što su samoprocjena religioznosti, uvjerenje o postojanju Boga i institucionalna religijska praksa.

Rezultati pokazuju da su ispitanici koji se smatraju agnosticima skloniji prihvaćanju koncepcije »kiborga«, a oni koji se smatraju uvjerenim ateistima skloniji prihvaćanju koncepcije »djeteta po narudžbi«, za razliku od ispitanika koji se smatraju religioznima.

Tablica 10. Koncepcije poslijeljudskog života s obzirom na samoprocjenu religioznosti

\begin{tabular}{|c|c|c|c|c|c|}
\hline & & $M$ & $s$ & & Kontrast \\
\hline \multirow{4}{*}{$»$ Kiborg« } & $\begin{array}{l}\text { uvjereni } \\
\text { ateisti }\end{array}$ & 0,2537 & 0,7648 & \multirow{4}{*}{$\begin{array}{c}F=4,573 \\
p<0,01\end{array}$} & \multirow{4}{*}{$2>4$} \\
\hline & agnostici & 0,5386 & 0,7714 & & \\
\hline & $\begin{array}{l}\text { nereligiozne } \\
\text { osobe }\end{array}$ & $-0,0228$ & 0,9831 & & \\
\hline & $\begin{array}{l}\text { religiozne } \\
\text { osobe }\end{array}$ & $-0,0556$ & 1,012 & & \\
\hline \multirow{4}{*}{$\begin{array}{l}\text { »Dijete po } \\
\text { narudžbi« }\end{array}$} & $\begin{array}{l}\text { uvjereni } \\
\text { ateisti }\end{array}$ & 0,5450 & 0,9813 & \multirow{4}{*}{$\begin{array}{l}F=6,475 \\
p<0,001\end{array}$} & \multirow{4}{*}{$1>4$} \\
\hline & agnostici & 0,0086 & 1,019 & & \\
\hline & $\begin{array}{l}\text { nereligiozne } \\
\text { osobe }\end{array}$ & 0,1000 & 0,9735 & & \\
\hline & $\begin{array}{l}\text { religiozne } \\
\text { osobe }\end{array}$ & $-0,0805$ & 1,015 & & \\
\hline
\end{tabular}

Analiza koncepcija poslijeljudskog života s obzirom na uvjerenje o postojanju Boga pokazuje da su ispitanici nesigurni po pitanju postojanja Boga i oni koji vjeruju da "postoji neka vrsta duha ili životne sile« skloniji prihvaćanju koncepcije »kiborga«, za razliku od ispitanika koji iskazuju vjerovanje $\mathrm{u}$ "postojanje osobnog Boga«. Ispitanici nesigurni po pitanju postojanja Boga skloniji su prihvaćanju koncepcije »djeteta po narudžbi«, za razliku od ispitanika koji vjeruju u »postojanje osobnog Boga«. 
Tablica 11. Koncepcije poslijeljudskog života s obzirom na uvjerenje o postojanju Boga

\begin{tabular}{|c|c|c|c|c|c|}
\hline & & $M$ & $s$ & & Kontrast \\
\hline \multirow{4}{*}{ »Kiborg« } & $\begin{array}{l}\text { Ne mislim da postoji } \\
\text { neka vrsta duha, } \\
\text { Bog ili životna sila. }\end{array}$ & 0,1073 & 0,8852 & \multirow{4}{*}{$\begin{array}{c}F=10,533 \\
p<0,001\end{array}$} & \multirow{4}{*}{$2,3>4$} \\
\hline & $\begin{array}{l}\text { Ne znam što da } \\
\text { mislim. }\end{array}$ & 0,1194 & 0,9957 & & \\
\hline & $\begin{array}{l}\text { Postoji neka vrsta } \\
\text { duha ili životne sile. }\end{array}$ & 0,1766 & 1,049 & & \\
\hline & $\begin{array}{l}\text { Postoji osobni Bog } \\
\text { (Bog - osoba). }\end{array}$ & $-0,1839$ & 0,9792 & & \\
\hline \multirow{4}{*}{$\begin{array}{l}\text { »Dijete po } \\
\text { narudžbi« }\end{array}$} & $\begin{array}{l}\text { Ne mislim da postoji } \\
\text { neka vrsta duha, } \\
\text { Bog ili životna sila. }\end{array}$ & 0,4570 & 0,8920 & \multirow{4}{*}{$\begin{array}{l}F=9,458 \\
p<0,001\end{array}$} & \multirow{4}{*}{$2>4$} \\
\hline & $\begin{array}{l}\text { Ne znam što da } \\
\text { mislim. }\end{array}$ & 0,1997 & 0,9248 & & \\
\hline & $\begin{array}{l}\text { Postoji neka vrsta } \\
\text { duha ili životne sile. }\end{array}$ & $-0,0001$ & 1,004 & & \\
\hline & $\begin{array}{l}\text { Postoji osobni Bog } \\
\text { (Bog - osoba). }\end{array}$ & $-0,1286$ & 0,9997 & & \\
\hline
\end{tabular}

S obzirom na institucionalnu religijsku praksu rezultati analize pokazuju da su ispitanici koji uopće ne idu na misu i oni koji to čine rijetko skloniji prihvaćanju koncepcije »kiborga«, za razliku od ispitanika koji na misu odlaze mjesečno i tjedno. Ispitanici koji uopće ne odlaze na misu te oni koji odlaze rijetko i povremeno skloniji su prihvaćanju koncepcije »dijete po narudžbi«, za razliku od onih koji na misu odlaze tjedno.

Tablica 12. Koncepcije poslijeljudskog života s obzirom na institucionalnu religijsku praksu

\begin{tabular}{|c|c|c|c|c|c|}
\hline & & $M$ & $s$ & & Kontrast \\
\hline \multirow{5}{*}{$\gg$ Kiborg« } & nikada & 0,1491 & 0,9870 & \multirow{5}{*}{$\begin{array}{l}F=9,101 \\
p<0,001\end{array}$} & \multirow{5}{*}{$1,2>4,5$} \\
\hline & $\begin{array}{l}\text { jednom godišnje } \\
\text { i rjeđe }\end{array}$ & 0,2572 & 0,9672 & & \\
\hline & $\begin{array}{l}\text { samo za vjerske } \\
\text { blagdane }\end{array}$ & 0,0152 & 1,028 & & \\
\hline & jednom mjesečno & $-0,1055$ & 1,016 & & \\
\hline & $\begin{array}{l}\text { jednom tjedno i } \\
\text { češće }\end{array}$ & $-0,2190$ & 0,9646 & & \\
\hline
\end{tabular}




\begin{tabular}{|c|c|c|c|c|c|}
\hline \multirow{5}{*}{$\begin{array}{l}\text { »ijete } \\
\text { po } \\
\text { narudžbi« }\end{array}$} & nikada & 0,0855 & 0,9771 & \multirow{5}{*}{$\begin{array}{l}F=8,067 \\
p<0,001\end{array}$} & \multirow{5}{*}{$1,2,3>5$} \\
\hline & $\begin{array}{l}\text { jednom godišnje } \\
\text { i rjeđe }\end{array}$ & 0,1277 & 1,049 & & \\
\hline & $\begin{array}{l}\text { samo za vjerske } \\
\text { blagdane }\end{array}$ & 0,1277 & 1,081 & & \\
\hline & jednom mjesečno & $-0,0487$ & 1,002 & & \\
\hline & $\begin{array}{l}\text { jednom tjedno i } \\
\text { češće }\end{array}$ & $-0,2386$ & 0,8997 & & \\
\hline
\end{tabular}

\section{Zaključak}

Tijekom povijesti Zapadnog svijeta razvoj novih tehnologija uglavnom je pobuđivao pomiješane osjećaje opreza i straha te nade i ushićenja. Primjerice, razvoj informacijsko-komunikacijskih tehnologija (računala, internet, mobilni telefoni itd.) u posljednjih dvadesetak godina prošlog stoljeća otvorio je nade u nove mogućnosti obnove zajedništva i zajednica, decentralizacije i revitalizacije demokracije, ravnopravnosti i pravednijeg razvoja, raskida s dominantnom logikom moći i nove mogućnosti u smislu izgradnje društvenih i individualnih identiteta. No, s druge strane, vrlo brzo su se pojavila i upozorenja o utjecaju tog razvoja na stvaranje jedne »kulture površnosti«, o produbljivanju postojećih socioekonomskih i svih drugih razlika i, danas vrlo aktualni, strahovi o stvaranju globalnog »virtualnog panoptikona« (Rheingold, 2000; Turkle, 1996; O’Hara i Stevens, 2006; Nakamura, 2008). Slično je i s razvojem biotehnologije za koji Rifkin ističe kako »predstavlja naše najdublje nade i težnje, ali isto tako i naše najmračnije strahove i zle slutnje«, prije svega jer se »[t]a tehnologija dotiče [...] srži našeg samoodređenja« (Rifkin, 1999: 14). Razvoj tehnoznanstvenog sustava, potpomognutog kapitalističkom ekonomijom, svojim »biousmjerenjima« predstavlja brzinu kao neupitnu vrijednost (Hassan, 2009) i »oslobođenje« (Virilio, 1999) koje s jedne strane potiče stanje »neprestane ushićenosti« (Bruckner, 2001), a s druge stvara »sindrom Frankensteina« (Best i Kellner, 2001). »Ono što moramo shvatiti, to zapadnoj civilizaciji gleda u oči već pola stoljeća: naime, da se pretežno megatehnička privreda može održati u unosnom djelovanju samo sistematskom i trajnom ekspanzijom. Umjesto jedne uravnotežene privrede, usmjerene na unapređivanje života, megatehnika zahtijeva neograničeno širenje kolosalnih razmjera, što je majstorija koja se može izvesti samo ratom ili nekom zamjenom za rat - gradnjom raketa i svemirskim istraživanjem« (Mumford, 1986: 381). 
U tom kontekstu u ovom radu smo analizirali koncepcije poslijeljudskog života jer, primjerice, upravo koncepcija kiborga predstavlja prijelaz s dominacije istraživanja svemira na dominaciju istraživanja »unutrašnjeg svemira«, odnosno ljudskog tijela i svijesti.

S obzirom na dobivene rezultate možemo reći da potvrđuju opću hipotezu rada. Na svim tvrdnjama, koje sadržajno obuhvaćaju spomenute koncepcije poslijeljudskog života, dobiven je znatno veći postotak ispitanika koji se s njima ne slažu, od postotka onih koji se s tim tvrdnjama slažu. To su i očekivani rezultati s obzirom na pretpostavljenu tradicionalnost sociokulturnog konteksta suvremenog hrvatskog društva. No ovako pojednostavljen zaključak tek je djelomice točan. Naime, dobiveni rezultati pokazuju da se $33,3 \%$ ispitanika slaže s tvrdnjom da je »stvaranje djeteta po narudžbi uz pomoć genske tehnologije privatna stvar pojedinca«. Otprilike 26,0\% ispitanika slaže se s tvrdnjama da »postoji bitna sličnost između rada ljudskog mozga i rada računala«, te da »ljudsko tijelo kakvo poznajemo nije konačan i nepromjenjiv oblik, nego jedan od mogućih oblika na putu ljudske evolucije«. Nadalje, rezultati empirijskog istraživanja, provedenog 2008. godine u sklopu međunarodnog projekta »European Values Study «, između ostalog, pokazuju da 68,0\% ispitanika u Hrvatskoj odobrava želju žene da »ima dijete kao samohrana majka i ne želi stabilnu vezu s muškarcem «, što je jedan od najviših rezultata u Europi na tom pitanju. ${ }^{6}$ Također, prema rezultatima istog istraživanja, 42,0\% ispitanika u Hrvatskoj odobrava »liječnički potpomognutu inseminaciju ili umjetnu oplodnju«, za razliku od 25,0\% u Italiji, 26,0\% u Irskoj i 27,0\% u Poljskoj, ali i 53,0\% u Španjolskoj.

Navedeni rezultati jasno pokazuju da pretpostavljena tradicionalnost suvremenog hrvatskog društva nikako nije jednoznačna. Stoga su potrebne daljnje analize u svrhu jasnije spoznaje odnosa između sociokulturnog konteksta suvremenog hrvatskog društva, posebice sustava vrijednosti, i mogućnosti i prijepora koje donosi razvoj biotehnologije i bioznanosti.

\footnotetext{
${ }^{5}$ Više o samom projektu i rezultatima istraživanja za Hrvatsku vidjeti u: »Europsko istraživanje vrednota - EVS - 2008. Podatci za Republiku Hrvatsku« (Bogoslovska smotra, god. 80, 2010, br. 2, str. 397-666).

${ }^{6} \mathrm{U}$ empirijsko istraživanje za 2008. godinu uključene su četrdeset i četiri europske zemlje. Viši postotak odobravanja na navedenom pitanju je na Islandu $(87,0 \%)$ i u Španjolskoj (80,0\%). U susjednim zemljama rezultati su: Srbija (62,0\%), Slovenija (59,0\%), Bosna i Hercegovina (56,0\%), Crna Gora (52,0\%). Osim već spomenute Španjolske, rezultati za ostale »katoličke zemlje« su uglavnom znatno niži, primjerice: Italija (31,0\%), Irska $(39,0 \%)$, Poljska (45,0\%), Slovačka $(31,0 \%)$.
} 
Rezultati koje smo ovdje prikazali i ukratko analizirali vrlo su ograničenog dosega, prije svega zato što su dobiveni u sklopu empirijskog istraživanja koje se nije bavilo ovom temom, što znatno ograničava mogućnosti daljnje analize. Nadalje, u radu ne analiziramo prihvaćenost praktične primjene biotehnologije u »terapijske svrhe«, nego idejni konstrukt »poboljšavanja ljudskog života« koji smjera »poslijeljudskom«. Spomenuti smjer analize smanjuje mogućnost jasnijeg određenja ispitanika zbog jednostavnog razloga - manje je povezan sa svakodnevnim životnim potrebama i problemima.

Nakon kratkih napomena o teorijskim i empirijskim ograničenjima ovog rada osvrnut ćemo se ukratko na postavljene radne hipoteze. Rezultati analize potvrđuju prvu hipotezu - ispitanici mlađe životne dobi (do trideset godina) skloniji su promatranim koncepcijama poslijeljudskog života, za razliku od ispitanika starije životne dobi. Druga hipoteza nije potvrđena. Statistički značajna razlika u pretpostavljenim odnosima dobivena je samo na jednoj koncepciji (»kiborg«). Treća hipoteza je potvrđena. Ispitanici politički »lijevo« orijentirani skloniji su promatranim koncepcijama poslijeljudskog života, za razliku od onih koji su politički »desno« orijentirani. Nadalje, rezultati analize ne potvrđuju četvrtu hipotezu koja je pretpostavljala višestruke odnose između samoprocjene religioznosti, uvjerenja o postojanju Boga i institucionalne religijske prakse i koncepcija poslijeljudskog života. Dodatnim analizama provjerili smo odnose između dobne strukture, političkih i religijskih orijentacija. Rezultati upućuju na jasnu povezanost političkih i religijskih orijentacija, dok u ostalim odnosima ta povezanost nije jednoznačna. Stoga možemo istaknuti dobnu strukturu kao određujuću karakteristiku u smislu (ne)prihvaćanja koncepcija poslijeljudskog života u hrvatskom društvu. S obzirom na spomenuta ograničenja daljnja obrazloženja ne možemo temeljiti na analizi rezultata tog empirijskog istraživanja. Jedan od mogućih odgovora na pitanje zašto su mladi skloniji koncepcijama poslijeljudskog života, za koji (barem za sada) nemamo jasnijih potvrda u rezultatima empirijskih istraživanja u Hrvatskoj, jest i promjena konstrukcije i prezentacije "graničnih bića« (primjerice »vampira«, »kiborga«, »klonova«, »mutanata« itd.) u popularnoj kulturi u posljednjih dvadesetak godina (Badmington, 2005; Bradford i dr., 2008). Tu promjenu Kate O'Riordan označava kao prijelaz od horora, dvojbenosti, do poželjnosti i nade (O'Riordan, 2008). Čini se kako popularnom kulturom (filmovi, serije, knjige i sl.) sve više dominiraju »socijalno poželjna čudovišta« koja postaju sve "prirodniji- 
ma«. Znači li to da i mi, ljudska bića, postajemo sve »neprirodnijima«? (Biocca, 1997). Shvaćamo li uopće ozbiljnost takve tvrdnje?

\section{LITERATURA}

Asimov, Isaac (1993 [1950]). I, Robot. London: HarperCollins Publishers.

Badmington, Neil (2003). »Theorizing Posthumanism«, Cultural Critique, 53: 10-27.

Badmington, Neil (2005). Alien Chic: Posthumanism and the Other Within. London: Routledge.

Baloban, Josip (ur.) (2005). U potrazi za identitetom. Komparativna studija vrednota: Hrvatska i Europa. Zagreb: Golden marketing-Tehnička knjiga.

Best, Steven i Kellner, Douglas (2001). The Postmodern Adventure: Science, Technology, and Cultural Studies at the Third Millenium. London: Routledge.

Biocca, Frank (1997). »The Cyborg's Dilemma: Progressive Embodiment in Virtual Environments«, Journal of Computer-Mediated Communication, 3 (2), http://jcmc.huji.ac.il/vol3/issue2/biocca2.html (12. 12. 1999.).

Bostrom, Nick (2005). »In Defense of Posthuman Dignity«, Boethics, 19 (3): 202214.

Bradford, Clare, Mallan, Kerry, Stephens, John i McCallum, Robyn (2008). New World Orders in Contemporary Children's Literature: Utopian Transformations. New York: Palgrave Macmillan.

Bruckner, Pascal (2001 [2000]). Neprestana ushićenost: esej o prisilnoj sreći. Zagreb: Društvo hrvatskih književnika.

Cifrić, Ivan (2003). Ruralni razvoj i modernizacija: prilozi istraživanju ruralnog identiteta. Zagreb: Institut za društvena istraživanja.

Clynes, Manfred E. i Kline, Nathan S. (1960). „Cyborgs and Space«, Astronautics, September: 26-27, 74-76.

Črpić, Gordan i Mravunac, Damir (2011). »Pregled postotaka istraživanja 'Supsidijarnost u hrvatskom društvu'«, Bogoslovska smotra, 81 (4): 731-752.

Črpić, Gordan i Zrinščak, Siniša (2010). »Dinamičnost u stabilnosti: religioznost u Hrvatskoj 1999. i 2008. godine«, Društvena istraživanja, 19 (1-2): 3-27.

Escobar, Arturo (2000). »Welcome to Cyberia: Notes on the Anthropology of Cyberculture«, u: David Bell i Barbara M. Kennedy (ur.). The Cybercultures Reader. London i New York: Routledge, str. 56-76.

Feenberg, Andrew (2000). »Will the Real Post-human Please Stand Up! A Response to Elichirigoity«, Social Studies of Science, 30 (1): 151-157.

Foucault, Michel (2002 [1966]). The Order of Things: An Archaeology of the Human Sciences. London i New York: Routledge.

Fukuyama, Francis (2003 [2002]). Kraj čovjeka? Naša poslijeljudska budućnost: posljedice biotehnološke revolucije. Zagreb: Izvori.

Graham, Elaine (2004). »Post/Human Conditions«, Theology \& Sexuality, 10 (2): $10-32$. 
Gray, Chris Hables, Mentor, Steven i Figueroa-Sarriera, Heidi J. (1995). »Cyborgology: Constructing the Knowledge of Cybernetic Organisms«, u: Chris Hables Gray, Heidi J. Figueroa-Sarriera i Steven Mentor (ur.). The Cyborg Handbook. New York i London: Routledge, str. 1-15.

Habermas, Jürgen (2006 [2001]). Budućnost ljudske prirode: na putu prema liberalnoj eugenici? / Vjerovanje i znanje. Zagreb: Naklada Breza.

Harris, John (2007). Enhacing Evolution: The Ethical Case for Making Better People. Princeton i Oxford: Princeton University Press.

Hassan, Robert (2009). Empires of Speed: Time and the Acceleration of Politics and Society. Boston: Brill.

Hayles, N. Katherine (1999). How We Became Posthuman: Virtual Bodies in Cybernetics, Literature, and Informatics. Chicago: University of Chicago Press.

Hayles, N. Katherine (2006). »Unfinished Work: From Cyborg to Cognisphere«, Theory, Culture \& Society, 23 (7-8): 159-166. doi:10.1177/0263276406069229

Horrobin, Steven (2006). »Immortality, Human Nature, the Value of Life and the Value of Life Extension«, Bioethics, 20 (6): 279-292. doi:10.1111/j.14678519.2006.00506.x

Hughes, James (2004). Citizen Cyborg: Why Democratic Societies Must Respond to the Redesigned Human of the Future. Cambridge: Westview Press.

Kass, Leon R. (2001). »L'Chaim and Its Limits: Why Not Immortality?«, First Things, 113: 17-24, http://www.firstthings.com (06. 03. 2012.).

Kass, Leon R. (2003). »Ageless Bodies, Happy Souls: Biotechnology and the Pursuit of Perfection«, The New Atlantis: A Journal of Technology \& Society, 1: 9-28.

Lafontaine, Céline (2009). »Regenerative Medicine's Immortal Body: From the Fight against Ageing to the Extension of Longevity«, Body \& Society, 15 (4): 53-71. doi:10.1177/1357034X09347223

Le Breton, David (2004). »Genetic Fundamentalism or the Cult of the Gene«, Body \& Society, 10 (4): 1-20. doi:10.1177/1357034X04047853

Lister, Martin, Dovey, Jon, Giddings, Seth, Grant, Iain i Kelly, Kieran (2009). New Media: A Critical Introduction. 2nd ed. London i New York: Routledge.

Marinović Jerolimov, Dinka (2005). »Tradicionalna religioznost u Hrvatskoj 2004.: između kolektivnoga i individualnoga«, Sociologija sela, 43 (2): 303-338.

Moravec, Hans (1988). Mind Children: The Future of Robot and Human Intelligence. Cambridge, Mass.: Harvard University Press.

Mumford, Lewis (1986 [1970]). Mit o mašini. 2: Pentagon moći. Zagreb: Grafički zavod Hrvatske.

Nakamura, Lisa (2008). Digitizing Race: Visual Cultures of the Internet. Minneapolis: University of Minnesota Press.

Nikodem, Krunoslav (2004a). »Tehno-identiteti kiborga: rastvaranje jastva u interesu preživljavanja«, Socijalna ekologija, 13 (2): 175-196.

Nikodem, Krunoslav (2004b). »Religijski identitet u Hrvatskoj: dimenzije religijskog identiteta i socio-ekološke orijentacije«, Socijalna ekologija, 13 (3-4): 257-285. 
Nikodem, Krunoslav (2008). »Ljudsko - konačna granica: biotehnologija (ra)stvaranja i dolazak poslijeljudskoga«, Filozofska istraživanja, 28 (1): 209-221.

Nikodem, Krunoslav (2009). »Kiborzi i 'djeca po narudžbi’: prilog sociološkom istraživanju osnova cyber kulture«, Socijalna ekologija, 18 (2): 107-129.

O’Hara, Kieron i Stevens, David (2006). Inequality.com: Power, Poverty and the Digital Divide. Oxford: Oneworld Publications.

O’Riordan, Kate (2008). »Human Cloning in Film: Horror, Ambivalence, Hope«, Science as Culture, 17 (2): 145-162. doi:10.1080/09505430802062919

Rheingold, Howard (2000). The Virtual Community: Homesteading on the Electronic Frontier. Rev. ed. Cambridge: The MIT Press.

Rifkin, Jeremy (1999 [1998]). Biotehnološko stoljeće: trgovina genima u osvit vrlog novog svijeta. Zagreb: Naklada Jesenski i Turk i Hrvatsko sociološko društvo.

Rihtar, Stanko i Franc, Renata (2011). »Osnovni metodološki podatci o istraživanju«, Bogoslovska smotra, 81 (4): 727-729.

Robertson, John A. (1994). Children of Choice: Freedom and the New Reproductive Technologies. Princeton: Princeton University Press.

Seidel, Asher (2009). Inhuman Thoughts: Philosophical Explorations of Posthumanity. Lanham: Lexington Books.

Stelarc (2000). »From Psycho-Body to Cyber-System: Images as Post-Human Entities«, u: David Bell i Barbara M. Kennedy (ur.). The Cybercultures Reader. London i New York: Routledge, str. 560-576.

Terranova, Tiziana (2000). »Post-Human Unbounded: Artificial Evolution and High-Tech Subcultures«, u: David Bell i Barbara M. Kennedy (ur.). The Cybercultures Reader. London i New York: Routledge, str. 268-279.

Turkle, Sherry (1996). Life on the Screen: Identity in the Age of the Internet. London: Weidenfeld \& Nicolson.

Virilio, Paul (1999 [1995]). Brzina oslobađanja. Karlovac: Naklada DAGGK.

Webster, Frank (2002). »Cybernetic Life: Limits to Choice«, u: John Armitage i Joanne Roberts (ur.). Living with Cyberspace: Technology \& Society in the 21st Century. New York i London: Continuum, str. 34-42.

[Wiener, Norbert] Viner, Norbert (1964 [1954]). Kibernetika i društvo: ljudska upotreba ljudskih bića. Beograd: Nolit.

Wilson, Samuel i Haslam, Nick (2009). »Is the Future more or less Human? Differing Views of Humanness in the Posthumanism Debate«, Journal for the Theory of Social Behaviour, 39 (2): 247-266. doi:10.1111/j.1468-5914.2009.00398.x

Wolfe, Cary (2010). What is Posthumanism? Minneapolis: University of Minnesota Press. 


\section{Cyborgs and "Custom-made Babies" 2.0: Acceptance of Posthuman Life Conceptions in Croatian Society}

\section{Krunoslav NIKODEM}

Department of Sociology, Faculty of Humanities and Social Sciences, University of Zagreb, Croatia

knikodem@ffzg.hr

Ivana BRSTILO

Department of Sociology, Croatian Catholic University, Croatia ivana.brstilo@unicath.hr

Development of contemporary biotechnology and bioscience is opening many possibilities, questions and controversies, not only in the sense of broader social, cultural and economic changes, but largely in the sense of human identity construction and determination criteria for human beings. This paper is based on the theories of posthumanism, transhumanism and bioconservativism. In the empirical sense it is based on the results of a survey that was conducted during the year 2009 on the representative sample of Croatian adult citizens $(\mathrm{N}=$ 1000). "Cyborg" and "custom-made baby" are analyzed in this paper, as two conceptions of posthuman life. The general hypothesis is that these conceptions of posthuman life will not be accepted, mainly because of the traditional sociocultural context in Croatian society. Furthermore, several working hypotheses are proposed. Results have confirmed the general hypothesis; however most of the working hypotheses were not confirmed.

Key words: posthuman, posthumanism, transhumanism, bioconservativism, cyborg, "custom-made baby" 